\title{
Penerapan Model Pembelajaran Berbasis Think-Talk-Write (TTW) Untuk Meningkatkan Kemampuan Berpikir Logis Pada Siswa
}

\author{
Bambang \\ SDN Wonokusumo VII/46 Surabaya \\ J1. Wonosari Lor Baru No.21, Wonokusumo, Kec. Semampir, Kota Surabaya, Jawa Timur \\ mrbengbengdanyank@gmail.com
}

Abstract

The Think Talk Write (TTW) based learning model in school action research is applied to material regarding math problems in everyday life. The research was carried out with the aim of knowing whether the application of the Think Talk Write (TTW) based learning model for students of SD Negeri Wonokusumo VII / 46 Surabaya could improve their logical thinking skills in Mathematics. The research was conducted with a twocycle action mechanism. And based on the results of the analysis, it can be concluded that the application of the Think Talk Write (TTW) based learning model can improve logical thinking skills and improve student achievement at SD Negeri Wonokusumo VII / 46 Surabaya. This can be seen from the increase in students' logical thinking skills in improving their learning outcomes. The effectiveness of the application of the Think Talk Write (TTW) based learning model in improving student achievement of SD Negeri Wonokusumo VII / 46 is shown through an increase in the average post-test score, an increase in the percentage of classical completeness and an increase in the value of observations on students' logical thinking abilities. The average post-test score in cycle I was 74.25 and cycle II was 78.29. Classical completeness in cycle I $76 \%$ and cycle II $91 \%$. The average value of observations on students' logical thinking skills in the first cycle is 79.59 and the second cycle is 82.4 .

Keywords: Logical Thinking, Cooperative Learning Model, Think-Talk-Write Strategy

\begin{abstract}
Abstrak
Model pembelajaran berbasis Think Talk Write (TTW) dalam penelitian tindakan sekolah ini diterapkan pada materi menyangkut permasalahan matematika dalam kehidupan sehari-hari. Ppenelitian dilaksanakan dengan tujuan untuk mengetahui apakah penerapan model pembelajaran berbasis Think Talk Write (TTW) pada siswa SD Negeri Wonokusumo VII/46 Surabaya dapat meningkatkan kemampuan berpikir logis pada mata pelajaran Matematika. Penelitian dilakukan dengan mekanisme tindakan dua siklus. Dan berdasarkan hasil analisis maka dapat ditarik kesimpulan bahwa Penerapan model pembelajaran berbasis Think Talk Write (TTW) dapat meningkatkan kemampuan berpikir logis dan meningkatkan prestasi belajar siswa di SD Negeri Wonokusumo VII/46 Surabaya. Hal ini dapat diketahui dari peningkatan terhadap kemampuan berpikir logis siswa dalam meningkatkan hasil belajarnya. Efektifitas penerapan model pembelajaran berbasis Think Talk Write (TTW) dalam meningkatkan prestasi belajar siswa SD Negeri Wonokusumo VII/46 ditunjukkan melalui kenaikan ratarata nilai post tes, kenaikan persentase ketuntasan klasikal dan kenaikan nilai observasi pada kemampuan berpikir logis siswa. Rata-rata nilai post tes pada siklus I 74,25 dan siklus II 78,29. Ketuntasan klasikal pada siklus I 76\% dan siklus II 91\%. Rata-rata nilai observasi pada kemampuan berpikir logis siswa pada siklus I 79,59 dan siklus II 82,4.
\end{abstract}

Kata kunci: Berpikir Logis, Model Pembelajaran Kooperatif, Strategi Think-Talk-Write

Copyright (c) 2021 Bambang

Corresponding author: Bambang

Email Address: mrbengbengdanyank@gmail.com (Wonosari Lor Baru No.21, Wonokusumo, Kec. Semampir)

Received 22 March 2020, Accepted 24 April 2020, Published 30 April 2021

\section{PENDAHULUAN}

Proses pembelajaran di kelas adalah salah satu tahap yang sangat menentukan keberhasilan belajar siswa. Upaya untuk meningkatkan kualitas pendidikan dan pengajaran dapat dilakukan terhadap berbagai komponen seperti: siswa, guru, indikator pembelajaran, isi pelajaran, metode, media, dan evaluasi. Guru sebagai salah satu mediator dan komponen pengajaran mempunyai peranan 
Penerapan Model Pembelajaran Berbasis Think-Talk-Write (TTW) Untuk Meningkatkan Kemampuan Berpikir

yang sangat penting dalam mencapai tujuan pembelajaran dan sangat menentukan keberhasilan proses pendidikan, karena guru terlibat langsung di dalamnya.

Belajar siswa berkaitan dengan motivasi belajarnya, dalam hal ini hubungan antar siswa di kelas harus terjalin dengan baik. Siswa yang merasa tidak diterima oleh kelasnya akan merasa tidak betah berada dalam kelasnya itu, sehingga motivasi belajarnya pun berkurang (Karso, 1993-1994: 108). Oleh karena itu, guru perlu melakukan tindakan pengkondisian dimana siswa dapat melakukan kerja sama dalam kelompok yang lebih kecil dan salah satu strateginya adalah dengan pembelajaran berkelompok atau kooperatif, misalnya dengan pemberian tugas dan kerja kelompok.

Mengingat proses belajar siswa yang tergantung motivasi seperti yang telah diuraikan, maka penulis merasa perlu untuk memilih metode pembelajaran yang mencakup keduanya yaitu pembelajaran yang bersifat kooperatif dan pembelajaran yang berpusat pada siswa serta mampu mengkonstruksi pengetahuan konsep siswa. Untuk itu, penulis meneliti tentang penerapan pembelajaran think-talk-write yang termasuk pembelajaran kooperatif yang berpusat pada siswa. Selain itu, jika ditinjau dari langkah-langkah pembelajarannya model think-talk-write juga termasuk model pembelajaran yang beraliran konstruktivisme.

Model pembelajaran berbasis Think Talk Write (TTW) penting untuk diterapkan pada materi menyangkut permasalahan matematika dalam kehidupan sehari-hari. Proses Belajar Mengajar pengetahuan di sekolah umumnya dianggap tidak menarik, akibatnya banyak siswa yang kurang tertarik untuk mendalami mata pelajaran Matematika. Hal ini sangat disayangkan mengingat Matematika bersifat dinamis dan kompleks menyangkut keadaan nyata yang sangat dibutuhkan kemampuan berpikir logis untuk memahami gejala dan fenomena yang ada.

Permasalahan rendahnya kemampuan berpikir logis disebabkan adanya beberapa faktor. Faktor pertama adalah performance guru. Di SD, pembelajaran Matematika diampu oleh wali kelas atau kadang-kadang diampu oleh guru dengan latar belakang mata pelajaran lain. Bahkan tidak menutup kemungkinan satu guru selain mengampu pembelajaran Matematika juga mengampu mata pelajaran lainnya. Akibatnya kreatifitas dan kemampuan guru pun tidak maksimal. Guru-guru merasa kewalahan dalam mempersiapkan setiap mata pelajaran yang harus diampunya karena beban mengajar terlalu banyak.

Faktor kedua adalah sajian materi dalam buku-buku Matematika kurang memadai. Buku-buku Matematika umumnya tebal-tebal dengan bahasa baku yang sulit dicerna oleh siswa. Apalagi dengan seringnya berganti kurikulum maka buku-buku pun sering berganti. Selain masalah materi, keberadaan buku juga berkaitan dengan harga yang selalu naik sehingga orang tua kurang mampu untuk membelinya. Dalam buku-buku Matematika seringkali materinya terlalu berat dan sangat lengkap tidak sesuai dengan tingkat perkembangan kemampuan siswa, akibatnya siswa tidak mampu belajar mandiri.

Faktor ketiga adalah faktor model pembelajaran dan dukungan media pembelajaran yang sesuai. Banyak Guru Kelas menyampaikan pembelajarannya hanya ceramah atau tanya jawab, atau 
bahwa mencatat buku di papan tulis. Model-model yang lebih bervariasi tidak dijalankan karena keterbatasan waktu, media pembelajaran, dan kemampuan guru untuk menerapkan variasi model pembelajaran.

\section{METODE}

\section{Setting Penelitian}

Jenis penelitian yang dilakukan oleh peneliti yaitu penelitian tindakan sekolah, yang lazim disebut PTS. Dengan demikian, penelitian ini sifatnya berbasis sekolah, karena dilakukan dengan melibatkan komponen yang terdapat di dalam proses belajar mengajar di dalam beberapa kelas kelas, materi pelajaran, dan metode pembelajaran. Tujuan dari penelitian ini tidak lain adalah untuk meningkatkan kemampuan berpikir logis pada siswa melalui model pembelajaran berbasis Think Talk Write (TTW). Diharapkan dari penelitian ini hasil belajar dapat lebih maksimal.

Empat tahapan digunakan secara sistematis dalam proses penelitian ini, dan diterapkan dalam dua siklus, yaitu proses tindakan siklus I dan proses tindakan siklus II. Namun dalam hal ini, peneliti memerlukan kajian awal berupa renungan atau refleksi awal sebagai studi pendahuluan sebelum melakukan perencanaan penelitian. Hal ini dimaksudkan untuk mengetahui semua gejala atau informasi tentang situasi-situasi yang relevan dengan topik penelitian.

\section{Subjek Penelitian}

Penelitian ini dilaksanakan oleh penulis di SD Negeri Wonokusumo VII/46 dengan alamat Jl. Wonosari Lor Baru No. 21 Kecamatan Semampir Kota Surabaya. Pelaksanaan penelitian dan perbaikan dijadwalkan oleh penulis dengan jadwal sebagai berikut:

Tabel 1. Waktu Pelaksanaan Tindakan

\begin{tabular}{|l|l|c|c|c|}
\hline No & \multicolumn{1}{|c|}{ Jenis Kegiatan } & Jul & Agt & Sep \\
\hline 1 & Konsultasi dengan Pengawas. & M-1 & & \\
\hline 2 & Mengajukan proposal penelitian. & M-1 & & \\
\hline 3 & Mengajukan RPP & M-2 & & \\
\hline 4 & Revisi RPP. & M-3 & & \\
\hline 5 & Evaluasi kualitas RPP tahap akhir. & M-4 & & \\
\hline 6 & Konsultasi dengan Observer. & M-4 & M1-4 & \\
\hline 7 & Pelaksanaan siklus I. & & M1-4 & \\
\hline 8 & Pelaksanaan siklus II. & & M1-4 & \\
\hline 9 & Menyusun laporan tindakan. & & & M1-3 \\
\hline
\end{tabular}

Kelas yang dijadikan obyek perbaikan dan penelitian adalah kelas 4 dan kelas 5 dengan jumlah siswa sebanyak 231 siswa.

\section{Teknik Pengumpulan Data}

Adapun teknik pengumpulan data yang penulis gunakan dalam penelitian ini adalah teknik nontes dan teknik tes. Teknik nontes alat penilaian yang dipergunakan untuk mendapatkan informasi 
Penerapan Model Pembelajaran Berbasis Think-Talk-Write (TTW) Untuk Meningkatkan Kemampuan Berpikir Logis Pada Siswa, Bambang

tentang keadaan di tertes (testi, tercoba, inggris testee) tanpa dengan alat tes. Teknik nontes diperlukan untuk mendapatkan data yang tidak, atau paling tidak secara langsung, berkaitan dengan laku kognitif. Teknik ini diterapkan melalui kegiatan observasi dan pengumpulan dokumentasi.

Adapun teknik tes adalah teknik yang dilakukan untuk memperoleh data dengan menggunakan tes. Tes dilakukan sebanyak dua kali, yaitu pada siklus I dan pada siklus II. Materi tes mengacu pada aspek-aspek Kemampuan Berpikir Logis. Tes digunakan untuk mengukur dasar dan pencapaian prestasi (Arikunto, 2002:196). Hasil tes siklus I dianalisis tersebut dapat diketahui kelemahan siswa, yang selanjutnya sebagai dasar untuk melengkapi siklus II. Hasil siklus II dianalisis sehingga dapat diketahui peningkatan kemampuan Kemampuan Berpikir Logis melalui latihan terbimbing dengan media teks lagu.

\section{Validasi Data}

Uji instrumen ini menggunakan validitas isi dan permukaan. Validitas isi adalah derajat tes yang menggambarkan esensi, topik-topik, dan ruang lingkup tes yang dirancang untuk pengukuran, (Sevilla dalam Hardani 2006:39). Validitas isi dilakukan dengan menyesuaikan aspek keterampilan Kemampuan Berpikir Logis berdasarkan landasan teori yang ada.

Validitas permukaan (paras) adalah tipe validitas yang berkaitan dengan tipe tes. Tipe validitas ini tidak didukung oleh bukti-bukti bahwa tes tersebut dapat mengukur sesuatu (Sevilla dalam Hardani 2006:39). Validitas permukaan dilakukan dengan cara dikonsultasikan dengan dosen pembimbing dan guru., sehingga dari pendapat mereka dapat disepakati bahwa instrumen yang akan digunakan dalam penelitian sudah valid.

\section{Teknik Analisa Data}

Dalam penelitian ini teknik analisis datanya adalah mengunakan pendekatan metode kualitatif untuk menganalisis keaktifan dan kreatifitas siswa, dan juga menggunakan metode kuantitatif untuk menganalisis tingkat keberhasilan siswa dalam proses belajar, melalui cara pengambilan data hasil pretes dan posttest dengan memberi skor pada hasil tes.

Skor pada pilihan ganda berdasarkan metode rights only, yaitu hanya jawaban yang benar saja yang di beri skor. Adapun penghitungan sekor di lakukan dengan rumus sebagai berikut:

Tabel 2. Rumus Penghitungan Skor

\begin{tabular}{|l|l|}
\hline \multicolumn{1}{|c|}{ Skor ketuntasan belajar } & \multicolumn{1}{c|}{ Skor rata-rata } \\
\hline $\mathrm{S}=\frac{\sum \mathrm{R}}{\text { Jumlah Soal }} \times$ Skor max & $\mathrm{x}=\frac{\sum \mathrm{X}}{\sum \mathrm{N}}$ \\
$\begin{array}{l}\text { Keterangan: } \\
\mathrm{S}=\text { skor siswa } \\
\mathrm{R}=\text { jawaban siswa yang benar }\end{array}$ & $\mathrm{x}=$ nilai rata-rata \\
& $\sum \mathrm{X}=$ jumlah semua nilai siswa \\
\hline
\end{tabular}




\section{Indikator Kinerja}

Indikator kinerja dalam penelitian ini sebagaimana terinci dalam tabel berikut :

Tabel 3. Indikator Aktivitas Guru

\begin{tabular}{|c|l|}
\hline No & Indikator yang Diobservasi \\
\hline 1 & Persiapan \\
\hline 2 & Penugasan \\
\hline 3 & Perencanaan Kegiatan \\
\hline 4 & Investigasi dan Penyajian \\
\hline 5 & Finishing \\
\hline 6 & Monitoring dan Evaluasi \\
\hline
\end{tabular}

Tabel 4. Indikator Kemampuan Berpikir Logis Siswa

\begin{tabular}{|c|l|}
\hline No & Indikator yang Diobservasi \\
\hline & Proses \\
\hline 1 & Memahami masalah \\
\hline 2 & Menyelesaikan masalah \\
\hline 3 & Mengajukan dugaan baru \\
\hline 4 & Merencanakan strategi \\
\hline 5 & Mengecek jawaban \\
\hline & Hasil \\
\hline 6 & Pemahaman \\
\hline 7 & Pendeskripsian \\
\hline 8 & Kualitas nilai \\
\hline 9 & Tingkat kesulitan \\
\hline 10 & Ketepatan waktu \\
\hline
\end{tabular}

Tabel 5. Indikator Ketuntasan

\begin{tabular}{|l|c|c|c|c|}
\hline \multirow{2}{*}{ Kriteria } & \multicolumn{3}{|c|}{ Aspek yang Dinilai } & \multirow{2}{*}{$\begin{array}{c}\text { Total } \\
\text { Nilai }\end{array}$} \\
\cline { 2 - 4 } & Proses & Hasil & LKI & Nan \\
Sangat & $81-100$ & $81-100$ & $81-100$ & $81-100$ \\
\hline Baik & & & & \\
\hline Cukup & $61-80$ & $71-80$ & $71-80$ & $71-80$ \\
\hline Kurang & $<60$ & $61-70$ & $61-70$ & $61-70$ \\
\hline
\end{tabular}

\section{HASIL DAN DISKUSI}

\section{Deskripsi Kondisi Awal}

Kondisi awal yang dapat dijadikan dasar pertimbangan untuk melaksanakan penelitian tindakan ini adalah hasil rata-rata penyelesaian tugas yang dikerjakan siswa pada bulan Agustus 2018. Hasil tersebut adalah data empiris dari wawancara penulis dengan beberapa guru kelas lainnya semakin memperkuat kesimpulan penulis pada permasalahan utama yang muncul dan sebab rendahnya nilai pada materi memecahkan permasalahan perbandingan pecahan dalam kehidupan 
Penerapan Model Pembelajaran Berbasis Think-Talk-Write (TTW) Untuk Meningkatkan Kemampuan Berpikir

sehari-hari. Permasalahan tersebut yang menjadi obyek dalam penelitian tindakan ini yaitu kemampuan berpikir logis siswa.

\section{Deskripsi Siklus I}

Keadaan siswa pada hari Sabtu tanggal 8 September 2018 itu kelihatan lebih siap menerima pelajaran dengan menerapkan model pembelajaran berbasis Think Talk Write (TTW) dengan beberapa kolaborasi dengan metode dan teknik lain. Ketika guru melakukan apersepsi banyak siswa yang langsung memberikan tanggapan yang positif yang mengingatkan akan materi sebelumnya, sehingga materi untuk siklus pertama ini bisa dilaksanakan sesuai dengan rencana semula. Pada siklus yang pertama ini penulis memberikan tugas memecahkan permasalahan perbandingan pecahan dalam kehidupan sehari-hari. Dan 10 soal yang ada di LKI, hasilnya adalah sebagian besar siswanya sudah berhasil mengerjakan tugas.

Dengan diterapkannya model pembelajaran berbasis Think Talk Write (TTW) pada pertemuan yang pertama ini terlihat telah membawa hasil yaitu sebagian besar siswa antusias dalam mengikuti pelajaran. Hal ini dibuktikan dengan penilaian observasi pada kemampuan berpikir logis siswa dalam mengikuti proses belajar mengajar rata-rata sebesar 80,43 yang apabila dikonsultasikan dengan tabel kriteria indikator masih dalam kategori baik. Selain itu peningkatan hasil juga terlihat pada hasil post tes pada lembar kerja individu (LKI) siswa. Nilai rata-rata siswa mengalami kenaikan dari 64,95 pada pra siklus menjadi 74,84 dan siswa yang mencapai KKM atau ketuntasan belajar pada siklus ini sebanyak 175 siswa dengan persentase $76 \%$ atau naik $31 \%$ dari sebelumnya.

Dari hasil pengamatan penulis ternyata siswa sudah baik dalam mengerjakan tugas, baik itu Uraian Objektif maupun Pilihan ganda yang ada pada LKI, namun dalam menjabarkan hasil pengamatan dan resitasi masih mengalami kesulitan dalam hal mengungkapkan dalam kata-kata (permasalahan linguistik).

\section{Deskripsi Siklus II}

Keadaan siswa pada hari Sabtu tanggal 15 September 2018 itu kelihatan lebih siap dari pada pertemuan sebelumnya, ketika guru memberikan apersepsi banyak siswa yang langsung memberikan tanggapan yang positif yang mengingatkan materi sebelumnya, sehingga materi untuk siklus kedua ini bisa dilaksanakan sesuai dengan rencana semula.

Dengan diterapkannya model pembelajaran berbasis Think Talk Write (TTW) pada pertemuan yang kedua ini terlihat telah membawa hasil yaitu sebagian besar siswa antusias dalam mengikuti pelajaran. Hal ini dibuktikan dengan penilaian observasi pada kemampuan berpikir logis siswa dalam mengikuti proses belajar mengajar rata-rata sebesar 82,46 yang apabila dikonsultasikan dengan tabel kriteria indikator telah berada dalam kategori sangat baik.

Selain itu peningkatan hasil juga terlihat pada hasil post tes pada lembar kerja individu (LKI) siswa. Nilai rata-rata siswa mengalami kenaikan dari 74,84 pada siklus I menjadi 78,71 dan siswa yang mencapai KKM atau ketuntasan belajar pada siklus ini sebanyak 210 siswa dengan persentase $91 \%$ atau naik $15 \%$ dari sebelumnya. 


\section{Pembahasan}

Masalah pokok yang dihadapi guru baik pemula maupun yang sudah berpengalaman adalah pengelolaan kelas (Suryanto dalam Kurnia Triyuli, 1997). Pengeloaan kelas merupakan masalah tingkah laku yang kompleks dan guru menggunakannya untuk menciptakan dan mempertahankan kondisi kelas sedemikian rupa sehingga siswa dapat mencapai tujuan pengajaran secara efisien dan memungkinkan mereka dapat belajar. Dengan demikian pengelolaan kelas yang actif adalah syarat bagi pengajaran yang efektif.

Tugas utama yang paling sulit bagi seorang guru adalah pengelolaan kelas, lebih-lebih tidak ada satupun pendekatan yang dikatakan paling baik, semuanya berada pada tangan guru pada saat dia berperan sebagai actor pendidikan di depan kelas. Guru juga berperan sebagai sutradara yang bertanggung jawab terhadap berhasil atau tidaknya skenario yang sedang dimainkan di lokasi penelitian dan pelaksanaan tindakan.

Dari permasalahan yang ada model pembelajaran berbasis Think Talk Write (TTW) dapat meningkatkan kemampuan berpikir logis dan prestasi belajar siswa. Hal ini terbukti dari hasil penilaian hasil tes yang penulis berikan yaitu mencapai tingkat ketuntasan klasikal sebesar $76 \%$ pada siklus I dan $91 \%$ pada siklus II.

Dari data-data kuantitas pada sub bab sebelumnya, terbukti bahwa penerapan Model pembelajaran berbasis Think Talk Write (TTW) memiliki efektifitas untuk meningkatkan aktivitas, kesiapan dan hasil belajar. Hal ini juga terlihat dari tanjakan persentase jumlah siswa yang tuntas dari sebelum diterapkan metode pembelajaran ini hingga akhir siklus II.

Peningkatan ini jika ditelusuri lebih dalam adalah karena adanya faktor motivasi dari dalam diri siswa itu sendiri, apakah mereka mau mengoptimalkan seluruh potensi yang menjadi indikator penelitian sepenuh hati mereka atau tidak. Metode pembelajaran yang diterapkan hanyalah faktor stimulus untuk memunculkan pembiasaan pada diri siswa.

\section{KESIMPULAN}

Berdasarkan hasil penelitian di atas, maka dapat ditarik beberapa kesimpulan bahwa penerapan model pembelajaran berbasis Think Talk Write (TTW) dapat meningkatkan kemampuan berpikir logis dan meningkatkan prestasi belajar siswa di SD Negeri Wonokusumo VII/46 Surabaya. Hal ini dapat diketahui dari peningkatan terhadap kemampuan berpikir logis siswa dalam meningkatkan hasil belajarnya.

Efektifitas penerapan model pembelajaran berbasis Think Talk Write (TTW) dalam meningkatkan prestasi belajar siswa SD Negeri Wonokusumo VII/46 ditunjukkan melalui kenaikan rata-rata nilai post tes, kenaikan persentase ketuntasan klasikal dan kenaikan nilai observasi pada kemampuan berpikir logis siswa. Rata-rata nilai post tes pada siklus I 74,84 dan siklus II 78,71. Ketuntasan klasikal pada siklus I 76\% dan siklus II 91\%. Rata-rata nilai observasi pada kemampuan berpikir logis siswa pada siklus I 80,43 dan siklus II 82,4. 
Penerapan Model Pembelajaran Berbasis Think-Talk-Write (TTW) Untuk Meningkatkan Kemampuan Berpikir

Berdasarkan simpulan hasil penelitian tersebut, peneliti memberikan saran agar dalam pembelajaran sebaiknya memakai berbagai macam metode, yang sesuai dengan tingkat pengetahuan siswa sehingga siswa tidak bosan dan menerima pelajaran sebagai mestinya. Dalam pemberian tugas haruslah menggunakan banyak variasi, sehingga diharapkan siswa dalam mengerjakan tugasnya bisa bersemangat dan dapat memahami maksud dan tujuan dari tugas tersebut. Selain itu, dianjurkan agar sekali-kali memberikan reward, untuk memacu semangat siswa.

\section{UCAPAN TERIMA KASIH}

Terimakasih kami ucapkan kepada Bapak/Ibu Kepala Sekolah dan Guru-guru di SDN Wonokusumo VII/46 Surabaya yang telah memberikan kesempatan kepada peneliti dalam melaksanakan penelitian. Terimakasih kepada siswa yang telah ikut berpartisipasi dalam melaksanakan penelitian ini.

\section{REFERENSI}

Andik Purwanto. 2012. Jurnal Kemampuan berpikir logis siswa SMA Negeri 8 Kota Bengkulu dengan Menerapkan Model Inkuiri Terbimbing dalam pembelajaran Fisika. http://wahyurock.com/2012/06/kemampuan-berpikir-logis-matematika/pdf. Diakses tanggal 15 oktober 2013.

Adriani, M. Dunia Matematika. http: //www. Thinktalkwrite.2008.html

Budiyono. 2008. "Kesalahan Mengerjakan Soal Cerita Dalam Pembelajaran Matematika”. Jurnal Pendidikan Matematika FKIP Universitas Sebelas Maret.

Chatarina, Reviea. 2004. Model-model Pembelajaran Efektif. (http: //chatarinablogspot.com/ModelModel-PembelajaranEfektif.pdf)

DePorter, Bobbi. 2010. Quantum Learning. Bandung: Penerbit Kaifa.

Ghufron, M Nur, \& Rini Risnawita. S. 2012. Gaya Belajar Kajian Teoritik. Yogyakarta: Pustaka Belajar.

Hudoyo, H. 2003. Pengembangan Kurikulum Matematika dan Pelaksanaannya di Depan Kelas. Surabaya: Usaha Nasional

Marzuki, A. 2006. Implementasi Pembelajaran Kooperatif (Cooperative Learning) Dalam Upaya Meningkatkan Kemampuan Koneksi dan Pemecahan Masalah Matematik Siswa. Tesis pada PPS UPI. Bandung: Tidak diterbitkan.

Moleong, L.J. 2010.Metodologi Penelitian Kualitatif. Bandung: PT. Remaja Rosdakarya.

Nurhayati, Eti. 2010. Bimbingan Keterampilan dan Kemandirian Belajar. Bandung: Batic Press

Retna, Milda. 2013. "Proses Berpikir Siswa Dalam Menyelesiakan Soal Cerita Ditinjau Berdasarkan Kemampuan Matematika”. Jurnal Pendidikan Matematika STKIP PGRI Sidoarjo.

Sartika, Lidya. 2011. "Hubungan Kemampuan Berpikir Logis dengan Kemampuan Menulis Karangan Argumentasi Siswa Kelas X SMA Negeri 9 Padang”. (Skripsi). Padang: FBSS. UNP. 
Sugiyono. 2013. Memahami Penelitian Kualitatif. Bandung: CV. Alfabeta.

Tim Psikologi. 2013. Buku Babon Psikotes Super Lengkap. Jakarta: Vis Media

Tim MKPBM Universitas Pendidikan Indonesia. 2001. Strategi Pembelajaran Matematika. Bandung: Universitas Pendidikan Indonesia

Suherman, Erman dkk. 2003. Strategi Pembelajaran Matematika Kontemporer. Malang: IMSTEP JICA.

Suyitno, Amin. 2004. Dasar-Dasar Dan Proses Pembelajaran Matematika I. Semarang: Jurusan Matematika UNNES

Suseli. 2010. Perbandingan Hasil Belajar Matematika Siswa yang menggunakan Think Talk Write (TTW) dengan Metode Ekspositori (Studi Eksperimen Siswa Kelas VII SMP Negeri I Balongan Indramayu). IAIN Syekh Nurjati Cirebon.

Usman, Moh.Uzer. 2002. Menjadi Guru profesional. Bandung: PT. Remaja Rosdakarya

Yamin, M. 2008. Tktik Mengembangkan Kemampuan Individual Siswa. Jakarta: Gaung Persada Press. 